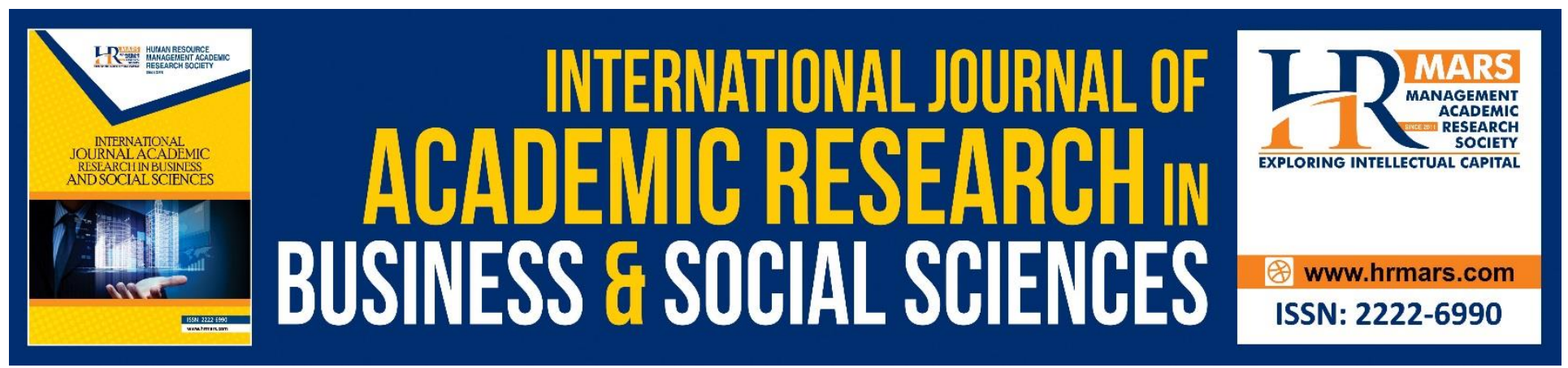

\title{
Impact of Deregulation on Residential Electricity Consumption in Nigeria: 1980-2017
}

\author{
Murtala Usman Tukur, Oyefabi Ilemobola Solomon
}

To Link this Article: http://dx.doi.org/10.6007/IJARBSS/v9-i6/5933

DOI: 10.6007/IJARBSS/v9-i6/5933

Received: 11 April 2019, Revised: 19 May 2019, Accepted: 01 June 2019

Published Online: 23 June 2019

In-Text Citation: (Tukur \& Solomon, 2019)

To Cite this Article: Tukur, M. U., \& Solomon, O. I. (2019). Impact of Deregulation on Residential Electricity Consumption in Nigeria: 1980-2017. International Journal of Academic Research in Business and Social Sciences, 9(6), 163-184.

Copyright: (C) 2019 The Author(s)

Published by Human Resource Management Academic Research Society (www.hrmars.com)

This article is published under the Creative Commons Attribution (CC BY 4.0) license. Anyone may reproduce, distribute, translate and create derivative works of this article (for both commercial and non-commercial purposes), subject to full attribution to the original publication and authors. The full terms of this license may be seen

at: http://creativecommons.org/licences/by/4.0/legalcode

Vol. 9, No. 6, 2019, Pg. 163 - 184

http://hrmars.com/index.php/pages/detail/IJARBSS

JOURNAL HOMEPAGE

Full Terms \& Conditions of access and use can be found at http://hrmars.com/index.php/pages/detail/publication-ethics 


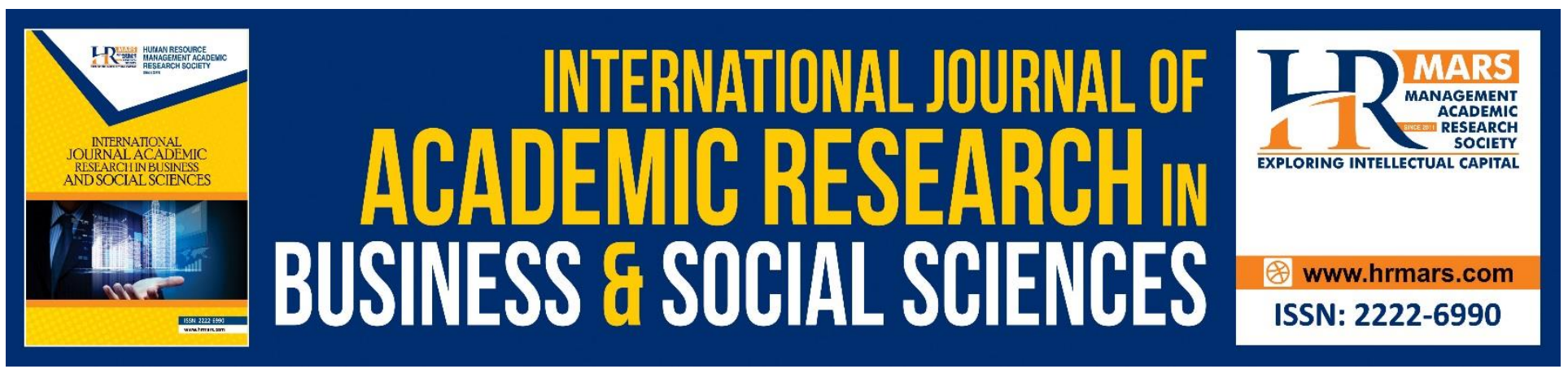

\title{
Impact of Deregulation on Residential Electricity Consumption in Nigeria: 1980-2017
}

\author{
Murtala Usman Tukur, Oyefabi llemobola Solomon \\ Department of economics, faculty of Arts and social sciences, Nigerian Defence Academy \\ Email: tukurmurtala15@gmail.com, Ilemobolaoye@gmail.com
}

\begin{abstract}
This study is an assessment of the impact of deregulation of the electricity market on the residential consumption of electricity in Nigeria from 1980 to 2017.Among the specific objectives set for the study are to examine the impact of deregulation on residential demand for electricity in Nigeria and to investigate if the residential demand for electricity in Nigeria responds to change in tariff (pricing)regime; Annual time series data on residential electricity consumption (REC), electricity tariff (ETA); income (ICM) and deregulation (a dummy variable) were collected from national electricity regulation council (NERC) and central bank of Nigeria (CBN) respectively and were analyzed using augmented dickey-fuller (ADF) and Philip-peron (PP) unit root test, co-integration test and vector error correction model (VECM), the result of the analysis shows the long run relation among the variables and the estimated long run elasticity values are:0.25 on income GDP and electricity price was -0.431 on the coefficient of deregulation (dummy) has negative sign and statistically significant suggesting that deregulation leads to a slight decline in electricity consumption. It is therefore recommended that, sustainable development of the electricity power industry should be ensured. Higher energy efficiency standards for electricity appliances, organized appropriate pricing policy and introduction of enlightenment campaign to educate people to be efficient in using electricity. Keywords: Deregulation, Electricity, Residential Electricity Consumption, Electricity Tariff.
\end{abstract}

\section{Background to the Study}

As far back as early nineteen centuries, the classical economists emphasized the economic benefit of deregulation however, it was not conceptualized, in their analysis, as an economic reform agenda. For example, Smith' (1776) analysis of the workings of an economy was focused on the essential elements of free market system (deregulation) while deemphasizing the control of the economy by government regulations. The arguments of the classists were based on the believed that the deregulated economy has an invisible stabilization mechanism which automatically drives it toward full employment. This was the philosophy championing the course of economic policy in the early nineteen centuries Di Bella and Grigoli (2016) 
As an economic concept, the assumptions underpinning deregulation are synonymous with assumptions of the capitalist economy. These assumption presupposes that the market operates in a competitive environment. That is the market forces of demand and supply determines prices of goods and services and the consumers' and producers' propensities to consume and produce respectively. It also determines the ways resources are allocated and the ways produced goods are distributed among competing needs. However, there are arguments that given the characteristics of deregulation, it will be difficult to have an entire economy deregulated. This is because the different sectors of an economy may have different characteristics and as such some countries, like Japan, Indonesia, South Korea and Nigeria have only deregulated some sectors (not the entire economy) of their economies Payne (2010)

In Nigeria, the power sector is one of the deregulated sector of the economy since 2005. Proponents of this exercise posit that the deregulation reform has the potentials of lowering the prices of electricity and enlighten its consumers on effective and efficient use of the product as well as use of modern appliances. This is expected to improve the amount of energy needed to provide needed services Udo,Chuku and Ekpan (2011).

The importance of electricity to household has both economic and social dimensions. The economic dimension correlates with its impact on economic growth, quality of life, and enhancement of labor productivity. The social dimension focuses on the impact of increased energy consumption on economic growth of a nation (Adebola, 2011). However, in the analysis of residential electricity demand, the idea of efficiency is virtually necessary. Energy efficiency connotes using energy in a manner that will minimize the amount of energy needed to provide services that are required. One of the ways to achieve this is to improve in the quality of the product.

The need to determine the nexus between deregulation and residential demand for electricity derives from the increasing realization of the mixed effect of deregulation on the residential demand for electricity. The motivation for deregulation exercise in most of the developing economies was inspired by the success the policy recorded in other countries across the world. For example, Japan enjoys improved electricity with deregulation of the sector in the early 1980s after suffering a long-term epileptic power supply since 1960s. This development has spark up the need to deregulate the power sector in other countries, both developed and the less developed.

The impacts of deregulation exercise are usually assessed both in the short-run and in the long-run. In the short run, consumer may have less expected incentives due to certain factors like inappropriate pricing policies and use of old or local appliances. These usually amount to inefficiency in the used of electricity. But in the long run, consumer will learn more on how to make use of electricity and also acquire modern electricity appliance instead of using local appliance. In other word, pricing policy may be stable in long run and serve as an incentive for encouraging efficient electricity consumption. This enables the individual household's and other users of electricity to have access to the product. Ishola (2005) explains further that power sector reforms are being pursued in order to make the sector more efficient and effective in addressing power demand and meeting the sustainable development agenda.

Households' demand for electricity serves as a source of welfare in meeting the demand for electricity at all time. This makes electricity to attain a very important position in every household 
(Tewathia, 2014). The demand for electricity in a household is derived from the electricity consuming appliances used by the household, therefore, the operating knowledge as well as electricity appliance should be efficient in order to maximize benefits and reduce the cost. Electricity is primarily used in the domestic sector for the following purposes thus; lighting, refrigerating, air-conditioning (ACs), water heating, etc. (World Bank 2008).

The link between energy and economic growth remains a key factor in development policy. Electricity (energy) use to play a magnificent role on economic growth of nations. Energy provides an essential ingredient for almost all human activities. It provides services for cooking and space/water heating, lighting, industry, food production and storage, education, mineral extraction, industrial production and transportation. Modern energy services are powerful engine of economic and social development, and no country has managed to develop much beyond a subsistence economy without ensuring at least minimum access to energy services for a broad section of its population. The modern civilization into which our lives centered depends on a variety of energy sources for its very existence. Energy use is a necessity for all human livelihood and development. It can change the way people live and their daily routine of activities.

The epileptic power supply in Nigeria is not only undermining the economic growth of the country but also affecting the relationship between the country and her trading partners. This is because of the existing gap between demand for and the supply of electricity despite efforts by the various past administrations to proffer solution to the problem. This is one of the reasons the sector was deregulated. Proponents of deregulation held that price incentive (regulation) by past administration is responsible for the dismal performance of the electricity sector leading to the widening gap between electricity supply and consumption.

The idea of deregulation usually intended to provide laudable solutions to existing problem noticed in the power sector; unfortunate in Nigeria it has rather compounded the crisis, considering the current wide gap between electricity supply and the required demand. From demand capacity of about $10,000 \mathrm{mw}$ of electricity, there is available consumption capacity of approximately $4000 \mathrm{mw}$, out of which $2500 \mathrm{mw}-3500 \mathrm{mw}$ has been used annually since 2002, National Electricity Regulatory Commission (NERC 2013). Despite, deregulation is in its second decade.

Apart from the price of electricity, there are other factors such as; income, level of technical progress, stock of appliances etc. that are responsible for the determination of electricity consumption and estimating residential demand for electricity at the micro level in the aftermath of deregulation. These factors, among others, adversely affects the consumption of electricity if not properly checked. Therefore, it is imperative to provide appropriate policy guide lines that will straighten the deregulation exercise to meet up its desired expectations. More importantly, inadequate knowledge makes it impossible for policy makers to evaluate the potential impact of deregulation on the residential demand for electricity and the economy at large.

The broad objective of this study is to assess the impact of deregulation of the electricity market on consumption of electricity by households in Nigeria, and the specific objectives are as follows:

1) Examine the factors influencing residential demand for electricity in Nigeria apart from price.

In addition, deregulation

2) Investigate the impact of deregulation on residential demand for electricity in Nigeria. 
3) Does residential demand for electricity in Nigeria respond to change in tariff (pricing) regime?

With regard to the above objective and the problem in assessing the impact of deregulation of the electricity market on consumption of electricity by households in Nigeria, the following questions are considered significant for this study.

I. What are the factors influencing residential demand for electricity in Nigeria apart from price and deregulation?

II. What is the impact of deregulation on residential demand for electricity in Nigeria?

III Does residential demand for electricity in Nigeria respond to change in tariff (pricing) regime?

In an attempt to address this and other related questions on assessment of the impact of deregulation of the electricity market on consumption of electricity by households in Nigeria. The following null hypothesis will be tested:

$\mathrm{H}_{01}$ : There are no significant factors influencing residential demand for electricity in Nigeria over the period of study.

$\mathrm{H}_{02}$ : Deregulation has no significant impact on residential demand for electricity in Nigeria.

$\mathrm{H}_{03}$ : Residential demand for electricity does not respond significantly to change in tariff (pricing) in Nigeria over the study period.

This paper consist of seven sections, following the introduction, section two discuss the literature reviews, the section three focuses on the presentation of the modelling framework of the paper, the section four present the techniques for data analysis, the section five present the empirical results, the penultimate section concludes, while the final section proffer solutions.

\section{Conceptual, Theoretical and Empirical Literature Conceptual View \\ Concept of Deregulation}

Privatization is the transfer of public enterprises ownership to private shareholders ownership; it is one of the revolutionary innovation in economic policies of both developed and developing countries Zaman et. Al (2015). Towards the end of 1980, the public enterprises that had grown too large began to suffer from fundamental problems of defective capital structures, excessive bureaucratic control and intervention, inappropriate technologies, gross incompetence and blatant corruption (Ishola, 2012).

Proponents of privatization argue that state control over public enterprises has divesting effects because it involves excessive public intervention in spite of the inherent inefficiency of government. Thus, encouragement of private entrepreneurship, the market and perfect competition is recommended as the solution to economic crisis in Nigeria. (Ojobo, 2005)

The United Nations Development Program (UNDP) Guidelines on Privatization (1991) defines it as the marketization of the public sector activity, that is the subjection of micro-economic decisionmaking to market forces, since this is a feature of profit-oriented private sector activity. Ezeani (2004; 24) on his own part defines it as a deliberate government policy of stimulating economic growth and efficiency by reducing state interference and broadening the scope of private sector activity through 
one or all of the following strategies, transfer of state owned assets to private ownership through the sale of shares, private control or management of state owned assets, encouraging private sector involvement in former public activity, and shifting decision making to agents operating in accordance with market indicators. Ojobo (2005) on his own part define privatization as the selling of a part or the entire equity of a publicly owned organization to private individuals or organizations such that the control of the public institution is transferred from government or any of its agencies to private hands.

\section{Concept of Electricity}

IMF Working Paper (2016). Electricity is the science, engineering, technology and physical phenomena associated with the presence and flow of electric charges. It is a secondary energy source which means that we get it from the conversion of other sources of energy, like coal, natural gas, oil, nuclear power and other natural sources, which are called primary sources

Electricity is generally measured in Kilowatt, Megawatt, and Gigawatt. The kilowatt hour (kWh) is a measure of electricity defined as a unit of work or energy, measured as one kilowatt (1,000watts) of power expended for one hour. On the other hand, Megawatt $(\mathrm{mW})$ refers to a unit of energy equivalent to 1000 kilowatt or 1,000,000 watts. Thus, Megawatt-hour (mWh) measures a unit of energy equivalent to one thousand kilowatt-hours or one million watt-hours (IEA, 2012). The kilowatt-hour is rarely used to express measurement of any form of energy other than electrical. So, if the energy is being transmitted or used at a constant rate (power) over a period of time, the total energy in kilowatt-hours is the product of the power in kilowatts and the time in hours. The kilowatthour is commonly used as a billing unit for energy delivered to consumers by electric utilities. The consumption of electrical energy by homes and small businesses is usually measured in kilowatthours. Larger businesses and institutions sometimes use the megawatt-hour. The energy outputs of large power plants over long periods of time, or the energy consumption of States or Nations, can be expressed in gigawatt hours (GWh).

\section{Residential Electricity Demand}

Residential electricity demand has been growing constantly, although the growth has slowed progressively since 1990's due to energy efficiency investments. The annual energy outlook by the EIA predicted that considering extended policies, which includes additional rounds of appliance standards and building codes in the future, residential electricity use will continue to grow, by $0.2 \%$ per year from 2012 to 2040, spurred by population growth and continued population shifts to warmer regions with greater cooling requirements Energy Information Administration (2015).

Taylor (1975) identify short run as a period in which the appliance stock of a household is assumed to be constant, hence the changes in electricity consumption occur due to changes in the utilization rate of the existing appliances. In long run the appliance holding can change. In the short run the residential demand for electricity is mainly determined by the price of electricity and the alternative forms of energy, income of the household, family size, number of rooms in the house, demographic factors like rural or urban area, temperature and seasonal factors and the appliance holding of the household. 


\section{Concept of Electricity Tariff}

Electricity tariff (price) this is the rate charge per unit of electricity consumed by the end user. It varies widely from country to country for several reasons. First, the price of power generation depends largely on the type and market price of the fuel used, government subsidies, industry regulation, and even local weather patterns.

Aminu, Peterside and Brown (2014) Electricity tariffs convey information on internal system operation to the actors involved. Electricity pricing is, then, of major importance both in liberalized and regulated systems. Most electricity consumers interact with the industry only through the price they pay for the service. Consequently, good tariff design reflects industry regulation as a whole and is the instrument used to provide consumers with the right signals.

Payne (2010) conversely, high electricity costs and electricity shortages act as a disincentive to investment, hamper competitiveness, and complicate efforts aimed at poverty reduction, all in all resulting in reduced efficiency and a bottleneck to economic activity. Inadequate management of the electricity sector usually brings about electricity rationing and costly subsidies, which are often exacerbated by fraud and nonpayment, or by weak enforcement.

\section{Theoretical Literature}

\section{Traditional Demand Theory}

The traditional demand theory depends on comparative statics which is an exercise where we analyze how the behavior changes when different variables (especially income and price) in the environment changes. That is, we try to predict what the behavioral response to deferent (to the consumer) exogenous changes should be. This sort of an exercise is what a large share of economics is about, and we will do it in many other applications. However, we will study what happens as prices and income changes for the consumer, which is the topic of traditional demand theory (one of the oldest and most well developed branches of economic theory). It is a usual phenomenon where demand curve slops downward from left to right indicating that consumers buy less quantity of goods at the higher prices than when the price is low. Therefore, price plays a very important role in determining the residential electricity consumption, perhaps, if price policies are not well improving it normally and discourages the consumption of electricity in the Household's and vice-versa.

\section{Energy Consumption Theory: Life-Cycle Cost Model}

This model is premised on energy consumption and appliance efficiency standards based on the observation that household derive value or utility not from direct consumption of energy - electricity, gas, petrol, kerosene, coal, etc. but rather from energy services that are produced when these fuels are used in conjunction with energy-using equipment such as refrigerators, air-conditioners, and water heaters. Thus, these appliances are example of energy services.

The regulatory assumption is that, in terms of prices faced by households in retail markets, the energy-efficiency trade-off canonically corresponds to a cost trade-off with more efficient equipment being more expensive to purchase initially while less expensive to operate. When combined with the assumption that both the level and characteristics of the underlying energy service are held constant across fuel combinations, and initial costs, operating characteristics, and future energy prices are known with certainty, the problem of minimizing the cost obtaining energy services is quite naturally 
captured by discounted cash flow or life-cycle cost. Therefore, within a given end-use energy category, for instance, different appliances require different levels of electricity input to produce a given level of energy service. Simply put, energy services have different energy engineering efficiencies. Thus, equivalently, in principle, a specific energy service output level can be produced by different combinations of energy and equipment. Put differently, there exists a fuel-efficiency tradeoff. Appliance standards act on this relationship by requiring a specific minimum efficiency or equivalently, all else being equal, a maximum energy demand - for a given equipment/appliance type and energy service.

\section{Cost Minimization Theory}

Berndt and Wood (1975) posit that energy could be considered as another input in the production process like labor, capital and raw materials. Since the objective of a rational firm is to minimize the cost, a firm should choose the combination of inputs that will minimize the cost of producing a given level of output. Thus, the firms demand for energy and other inputs is derived from the demand for the firm's product. From the formal solution to such a firm's cost minimization problem, the derived demand for inputs is determined by: output, production technology, the substitution possibilities between factors of production, and the relative prices of all the factors. From this argument, it is evident that energy is essential in production, thus forming a basis for a possible relationship between consumption of electricity and output of a production entity.

\section{Theory of Contestable Markets}

Baumol (1982) has developed the "Theory of contestable markets" which wants to show that such natural monopolies do not necessarily have to be in public hands nor be regulated by the state in order to achieve optimal allocation. The theory states that competition in the market is not necessary to bring about an optimal allocation in natural monopolistic markets. The threat of market entry, in other words potential competition is sufficient. One can take this as the attempt to generalize the model of perfect competition to cover all forms of markets by use of the model of the perfectly contestable market. The main emphasis is being laid on the potential competition- certainly under strongly idealized market conditions, for "'a contestable market is one into which entry is free, and exit is absolutely costless" (Baumol, 1982). However, these conditions are not in effect when "irreversible costs" (sunk costs) exist. These costs once spent - cannot be recovered by the firm concerned when exiting a market. Examples for these costs are expenditures for research and development and for underground pipeline - and communication networks. Since in these cases opportunity costs are zero - an alternative use is not possible (anymore), a cost asymmetry exists between the "established" firm and a potential new competitor who would have to make the correspondent fixed investment beforehand. Irreversible costs can therefore constitute a barrier of entry into the respective market and can give the existing enterprise a - even though not unlimited monopoly situation. This monopoly power can be used to reap monopoly profits at the detriment of the consumer. It is a fact that industries that show characteristics of natural monopolies are usually also characterized by the existence of substantial irreversible costs. This requires therefore appropriate public interventions in the form of regulations or public enterprises. Regulation and antitrust policy come from the same historic roots. Antitrust policy in the USA is based on the 
objective to organize the market processes by means of restriction-free competition. Public regulation is required when such competition fails to organize the market processes or cannot take effect at all. On one hand, economies of scale can lead to natural monopolies. On the other hand, due to special economic conditions, frequent and damage in price wars can break out and destroy productive capacities. In the first case, the regulating commission must monitor private monopoly power and in the second case, it must limit and regulate the competition. Both cases are about simulating competition in cases when it cannot take place or should not take place by bureaucratic decision-making processes. This is in regard to specific results like optimal allocation of resources, optimal price setting, quality of production and -safety. The European form of regulation has aimed and aims not only at the prevention of an exploitation of consumers and an abuse of market power, but had from the start "general economic policy" objectives (especially regional- and social policy goals).

The study adopted energy consumption theory (and life-cycle cost model) due to the fact that, the theory premised on energy consumption and appliance efficiency standards based on the observation that household derive value or utility not from direct consumption of energy (electricity, gas, petrol, kerosene, coal) etc. but rather from energy services that are produced when these fuels are used in conjunction with energy-using equipment. Moreover, this is highly consistent with the nature of energy (electricity) consumption.

\section{Empirical Review}

Liu, Gao, Hao, and Liao (2016) investigates how residential electricity consumption changes as incomes increase in China Using panel data from 30 provinces for the 1995-2012 period. They employed a reduced piecewise linear model that is self-adaptive and highly flexible and circumvents the problem of "prior restrictions". Robust tests of different segment specifications and regression methods are performed to ensure the validity of the research. The results provide strong evidence that the income elasticity was approximately one, and it remained stable throughout the estimation period. The income threshold at which residential electricity consumption automatically remains stable or slows has not been reached

Di Bella and Grigoli (2016) investigate poor performance of the electricity sector. They propose a number of models that account for different equilibria (some better, some worse) of the electricity sector. They show how policy choices (affecting insolvency prospects or related to rules for electricity dispatching or tariff setting), stochastic generation costs, and initial conditions, affect investment in generation and electricity supply. They also show how credible (non-credible) promises of stronger enforcement to reduce theft result in larger (smaller) electricity supply, lower (higher) government subsidies, and lower (higher) tariffs and distribution losses, which in turn affect economic activity. To illustrate these findings, the study reviews the experience of Haiti, a country stuck in a bad equilibrium of insufficient supply, high prices, and electricity theft; and that of Nicaragua, which is gradually transitioning to a better equilibrium of the electricity sector.

Nidhi Tewathia (2014) examined that electricity has attained a very important place in every household on this planet. It is a major contributor towards improvement of the standard of living of any individual, family and society at large. This paper aims to find out the monthly average household 
INTERNATIONAL JOURNAL OF ACADEMIC RESEARCH IN BUSINESS AND SOCIAL SCIENCES Vol. 9, No. 6, June, 2019, E-ISSN: 2222-6990 @ 2019 HRMARS

electricity consumption and seasonal variations in this consumption for the months of summer, winter and moderate weather for Delhi. The factors which influence the electricity consumption of a household have been examined by using a questionnaire based study of 395 Delhi households selected via stratified random sampling technique. Multiple regression models have been run to describe the pattern of household electricity consumption. The results from the study show that the stock of appliances in a household contributes the most to the variation in the dependent variable. An inverted U-shaped Non-linear Temperature- Electricity Curve has been derived from the primary data used in the study.

Mudassir et. al. (2016) examine the relationship between electricity consumption and its major determinants; number of electricity customers, electricity prices and electricity shortages in Pakistan using time series data from 1972 to 2012. The study employed the Johansen co-integration test to examine relationship between electricity consumption and its determinants. Multivariate granger causality test is then applied to determine the causality direction between electricity consumption and its major determinants.

Yanming Sun (2015) estimate electricity demand elasticity on price and income in the residential sector of USA, by using the annual state-level panel data for 48 states, I implored dynamic partial adjustment model. The analysis reveals that in the short run, one-unit price increase will only lead to 0.142 unit of reduction in electricity use after controlling for the endogeneity of electricity price. Thus, raising the energy price in the short run will not give consumers much incentive to adjust their appliances and make energy conservation investments to reduce electricity use. However, in the long run, one-unit price increase will lead to almost one-unit consumption reduction when the endogeneity of electricity price is controlled. Therefore, in the long run, facing the higher electricity price induced from regulation policies, consumers are more likely to adjust their stock of appliances and make energy efficiency investments, which lowers their electricity consumption.

Nwachukwu, Ezedinma, and Jiburum (2014) examines electricity consumption in these three sectors using time series data from 1970 to 2004. Analysis of variance technique was used in testing the hypothesis. The results suggest that electricity consumption differed significantly among the three sectors, with the exception of the industrial versus commercial sectors, at 0.01 level (Fcal=19.805, $\alpha$-sign $=.000)$. The residential sector has the highest mean electricity consumption (396.405 mw per hour). It is followed in descending order by industrial sector (9223.9429 mw per hour) and commercial sector (175.33629 mw per hour). A comparison of the mean electricity consumption in each of the three sectors with daily electricity demand of (5000mw per hour) shows that the three sectors are grossly under supplied with electricity. This reveals the root cause of power outages.

Eguabor (2014) examine evidence on the existence of asymmetries in the metering of electricity by the organization between January 2005 and November, 2013.Using Chiappori-Salanie correlation statistics and data from the response of 720 electricity consumers and 524 organization bills within the Benin Electricity Distribution Company, the study observed that the electricity bills were asymmetric. The asymmetries were observed for both the metered and unmetered consumers over the period. For the metered consumers, the asymmetry was more prevalent for the analogue than the prepaid meter users. The asymmetry existed mainly through procurement of meter in the case of the prepaid meter users. The study argues that estimated billings by the organization give 
INTERNATIONAL JOURNAL OF ACADEMIC RESEARCH IN BUSINESS AND SOCIAL SCIENCES Vol. 9, No. 6, June, 2019, E-ISSN: 2222-6990 @ 2019 HRMARS

room for asymmetry and overprices energy consumptions. This situation discourages consumption of electricity in Nigeria.

Holtedahl and Joutz, (2004) used ECM and included price of electricity as a determinant of its consumption, urbanization (as a proxy variable to capture economic development characteristics and electricity-using capital stocks that are not explained by income), population, income, price of oil and weather. They found that there was an increase in the consumption of electricity as households in towns and cities were more likely to be connected to the grid than those in the rural areas and the result suggested that short- and long-term effects are separated through the use of an error correction model.

Udo, Chuku, and Ekpeno (2011) used ARDL model to investigate the dynamics of aggregate electricity consumption in Nigeria, using annual time series data over the period 1970-2008. The estimated long run income elasticity was 0.58 which is statistically significant and is consistent with the theory that an increase in income will stimulate an increase in the demand for electrical goods and services other things equal. The short-run income elasticity is 0.22 which is less than that of the long run value of 0.58 but was significant. These values mean electricity is income inelastic. The values of population elasticity were 0.89 and 0.86 in the long-run and short-run respectively, and are statistically significant. This means increase population will increase the demand for electricity, therefore, it is a major determinant of electricity consumption. The value for the industrial elasticity is 0.17 in the long-run and -0.10 in the short-run with both being statistically significant. The shortrun coefficient of -0.10 supports the thesis at manufacturers in the sector have resorted to alternative means of generating electricity for their production process due to the epileptic power supply in the country.

Isola (2012) examines the challenges and prospects of power sector reform in Nigeria by employing a purely descriptive analysis. The focus of exposition is on the market structure, market design and supply gap in the electricity generation within the context of power reform. The study adopts oligopolistic game theory based models of Cournot, Bertrand and Supply Function Equilibrium to explain the complex interest groups in Nigeria energy sector and relate them to experiences in other countries. The study concludes with a number of suggestions that can move the power sector forward from its lack luster performance of the years.

\section{Model Specification}

The study makes use of price and income elasticity and estimate the residential demand for electricity in Nigeria. The approach was adopted from the earlier work of Udo, Chuku, and Ekpeno (2011) which examines aggregate consumption of electricity in residential sector in Nigeria. The study bases its theatrical foundation on energy consumption theory (life-cycle cost model). This model is premised on energy consumption and appliance efficiency standards based on the observation that household derive value or utility not from direct consumption of energy - electricity, but rather from energy services that are produced which is consistent with nature of electricity consumption. It is a log-linear multiple regression model that shows the relationship between residential demand for electricity and its determinants. In this study the functional form of the model is give in equation (1) as:

$R E C=f\left(E T A, I C M, D t, D_{d r g}, R_{t-1}\right)$ 
The relationship in equation (1) can be estimated by log-linear equation with partial elasticities as specified in equation (2) below:

$\log R E C t=\beta_{0}+\beta_{1} \log E T A t+\beta_{2} \log I C M t+\beta_{3} \log D_{d r g}+\beta_{4} R E C_{t-1}+\mu$

Where;

$\beta_{1}, \beta_{2}, \beta_{3}$ and $\beta_{4}$ are the short-run price and income elasticities while $\mu$ is the stochastic error term which is independently and identically normally distributed, $\beta_{0}$ is the constant term.

REC $=$ Residential Electricity Consumption

ETA = Electricity Tariff (proxy for price of electricity consumption)

$\mathrm{ICM}=$ Income

$D_{\mathrm{drg}}=$ Dummy for Deregulation $(D=1$, if it is deregulation era; and $D=0$, if otherwise)

$\beta_{\mathrm{o}}=$ intercept

$\beta_{1}, \beta_{2}, \beta_{3}, \beta_{4}=$ partial slopes

$\mu=$ stochastic random error term

The long-run model is given by autoregressive distributed lag model (ARDL) in equation (3) as:

$e_{t}=\delta_{0}+\delta_{1} e_{t-1}+\ldots .+\delta_{n} e_{t-n}+\phi_{1} P_{t}+\ldots \ldots .+\emptyset_{n} P_{t-n}+\phi_{1} y_{t}+\ldots .+\phi_{n} y_{t-1}$

so that: $\dot{\varepsilon}_{\mathrm{p}}^{\mathrm{SR}}=\emptyset_{1}$, and $\dot{\varepsilon}_{\mathrm{y}}^{\mathrm{SR}}=\phi_{1}$

to determine the long-run elasticities, let;

$\mathrm{e}^{*}=\mathrm{e}_{\mathrm{t}}=\mathrm{e}_{\mathrm{t}-1}=\mathrm{e}_{\mathrm{t}-2}=$

$p^{*}=p_{t}=p_{t-1}=p_{t-2}=$

$\mathrm{y}^{*}=\mathrm{y}_{\mathrm{t}}=\mathrm{y}_{\mathrm{t}-1}=\mathrm{y}_{\mathrm{t}-1}=$

substituting $3 a, 3 b$ and $3 c$ into 3 , we have:

$\mathrm{e}^{*}=\delta_{0}+\delta_{1} \mathrm{e}^{*}+\ldots .+\delta_{\mathrm{n}} \mathrm{e}^{*}+\phi_{1} \mathrm{P}^{*}+\ldots \ldots+\phi_{\mathrm{n}} \mathrm{P}^{*}+\phi_{1} \mathrm{Y}^{*}+\ldots .+\phi_{\mathrm{n}} \mathrm{y}^{*}$

$\left(1-\delta-\ldots \delta_{n}\right) \mathrm{e}^{*}=\delta_{0}+\left(\phi_{1}+\ldots .+\phi_{\mathrm{n}}\right) \mathrm{P}^{*}+\left(\varnothing_{1}+\ldots .+\emptyset_{\mathrm{n}}\right) \mathrm{y}^{*}$

By rearranging (5), we obtained:

$\mathrm{e}^{*}=\frac{\delta_{0}}{\left(1-\delta_{1}-\ldots \delta_{n}\right)}+\left(\varnothing_{1}+\ldots .+\emptyset_{n}\right) /\left(1-\delta_{1^{-}} \ldots \delta_{n}\right) \mathrm{P}^{*}+\left(\varnothing_{1}+\ldots .+\emptyset_{\mathrm{n}}\right) /\left(1-\delta_{1^{-}} \ldots \delta_{\mathrm{n}}\right) \mathrm{y}^{*} \ldots$

\section{Technique of Data Analysis}

\section{Augmented Dickey-Fuller (ADF) and Phillips-Peron (PP) Unit Root Tests}

Unit root test has been conducted in the study to avoid estimation of spurious regression and ensure efficiency of the result. Although there are a number of methods used to test for stationarity and the presence of unit roots, the Augmented Dickey Fuller (ADF) and the Phillip- Peron (PP) test will be used to determine the order of integration of the variables. A series is said to be stationary if it has a constant mean and a constant variation and/ or a covariance. On the contrary, a non-stationary series contains a clear time trend and has a variance that is not constant overtime. Usually, the unit root is conducted on individual variables and stated in three possible forms. The forms are model without intercept and trend, model with intercept but no trend and mo with intercept and trend. The ADF and PP equations are specified as shown below:

$\Delta \mathrm{Y}_{\mathrm{t}}=\mathrm{Y}_{\mathrm{t}}+\beta_{\mathrm{i}}$

$\Delta \mathrm{Y}_{\mathrm{t}}=\beta_{0}+\beta+\mathrm{e}_{2 \mathrm{i}}$

$\Delta Y_{t}=\gamma_{0}+\gamma_{1} t+\beta_{i}+e_{3 i}$ 
Where; $\mu_{\mathrm{i}}=(\mathrm{ICM}, \mathrm{ETA}, \mathrm{DRG}$ and $\mathrm{REC})$ representing the variables used for the unit root test.

The equation (7) represents random walk model without intercept and no trend; equation (8) represents random walk model with intercept but no trend while equation (9) represents random walk model with intercept and trend. One of the standard conditions required for the implementation of the ADF unit root test is that both the null and alternative hypotheses must be stated and tested. Therefore, we state the hypothesis as follows:

$H_{0}: \beta=1$, the presence of a unit root using either equation (7), (8) or (9).

$H_{1}: \beta \neq 1$, the absence of unit root using either of equation (7), (8) or (9).

\section{Co-integration Test and the Vector Error Correction Model (VECM)}

Engle and Granger (1987) pointed out that a linear combination of two or more non-stationary time series may be stationary. If such a stationary exists, the times series data so combined are said to be co-integrated. The stationary linear combination is called the co-integrating equation and may be interpreted as a long run equilibrium relationship between the variables.

The Johansen co-integration test have been use by this study to investigate the long relationship between variables (ICM, $\left.D_{d r g}, E T A\right)$ and REC. The equation is stated as:

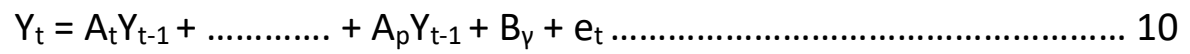

Where;

$\mathrm{Y}_{\mathrm{t}}=$ dimensional vector of non-stationary I (1) variable

$\gamma=\gamma$-dimensional vector of deterministic variable

$\mathrm{e}_{\mathrm{t}}=$ stochastic error residual

The error correction mechanism first used by Sargans (1984) and later popularized by Engle and Granger (1987) corrects for disequilibrium. The vector error correction (VEC) model is a restricted vector auto-regression (VAR) that has co-integrated restrictions build into the specification, so that it is designed with non-stationary series that are known to be co-integrated. The co-integration term is known as error correction term since the deviation from long run equilibrium is corrected gradually through a series of partial short run adjustment. The model is stated as:

$Y_{t}=\beta Y_{t-1}+e_{t}$ 11

\section{Priori Expectation}

This referred to the sign and sizes of the economic relationship among the variables of the model based on theoretical criteria. The expectations for the equation (1) are that all the parameters $\beta_{1}<0$; $\beta_{2}>0$ and $\beta_{3}>0$. This suggest that an increase in ETA and ICM, all other things being equal will decrease $R E C$ while an increase in $D_{\text {drg }}$ will increase $R E C$ respectively. 
INTERNATIONAL JOURNAL OF ACADEMIC RESEARCH IN BUSINESS AND SOCIAL SCIENCES

Vol. 9, No. 6, June, 2019, E-ISSN: 2222-6990 @ 2019 HRMARS

\section{Empirical Results}

Table 1: Summary of Descriptive Statistics of the Variables

\begin{tabular}{llll}
\hline & LETA & LGDP & LREC \\
\hline Mean & 1.179 & 0.214 & 6.512 \\
Median & 101.1 & 0.210 & 4562 \\
Maximum & 451.8 & 0.400 & 1455 \\
Minimum & 41.89 & 0.150 & 1030 \\
Std. Dev. & 0.852 & 0.052 & 3949 \\
Skewness & 2.179 & 1.689 & 0.862 \\
Kurtosis & 8.229 & 6.367 & 2.399 \\
Jarque-Bera & & & \\
Probability & 69.49 & 4.162 & 4.998 \\
& 0.000 & 0.103 & $0.182 \mathrm{~T}$ \\
Sum & & & 23440 \\
Sum Sq. Dev. & 4245 & 7.710 & $5.46 \mathrm{E}+08$ \\
\hline Observations & 25403 & 0.094 & 36 \\
\hline
\end{tabular}

\section{Source: e-views 9 Output}

The result of descriptive statistic computed to check the quality of the data set is reported in table 1. The results reveal that ETA, GDP and REC averaged 1.179, 0.214 and 6.12 respectively. All the variables, except REC, have minimum standard deviations suggesting that the estimates are as close as possible to their true mean values. The Jarque-Bera estimates of normality for all the variables, except ETA, are insignificant at 5\% level. This implies that the null hypothesis that the variables are normally distributed cannot be rejected. Also all the variables are positively skewed and the kurtosis estimates suggest a fairly robust result. 
Figure 1: Trend of Electricity Consumption and its Intensity (1980-2015)

\section{Source: e-views 9 Output}

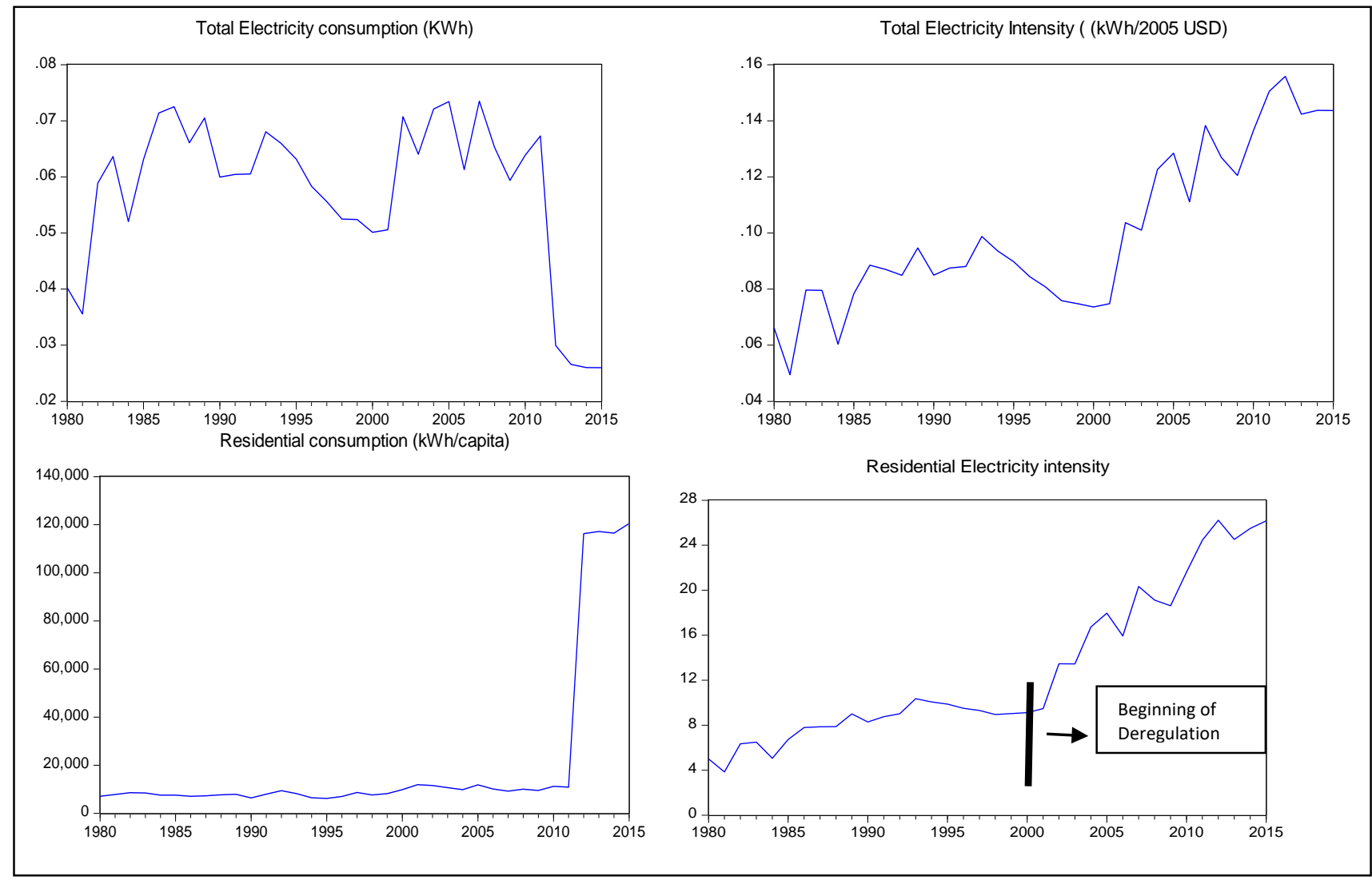

The figure 1 above shows the trends of total electricity consumption, total electricity intensity, residential electricity consumption and residential electricity intensity over 1980-2015. The result shows that both electricity consumption and electricity intensity have increased tremendously during the study period. This is in contrary to expectations from the impacts of deregulation. That suggest that an appropriate economic measures should be prepared such as proper pricing policies and efficient energy consuming policies in order to improves the residential electricity consumption situation. Even though, apart most economic factors there are other factor that use to decide the residential electricity consumption such as degree of urbanization rises the purchase of electricity appliances this leads to increase in electricity consumption and the intensity levels. Therefore, these should be considered during policy formulation issues. Holtedahl and Joutz (2004) assert that "the degree of urbanization is a reasonable proxy for electricity-using equipment since cities are electrified sooner than rural areas and are on the forefront of adopting modern household appliance". This improves the consumer efficiencies in electricity usage. While total electricity consumption has risen and falling, total electricity intensity exhibits an upward trend throughout the study period. This agree with the facts that electricity consumption depends largely on income (GDP), when income increases the per capita consumption of electricity increases and vise-vasa. Higher real per capita income will 
increase purchases of electrical equipment and hence increase electricity demand Babatunde and Shuaibu (2014). The intensity rises due to the fact that increase in income leads to the purchase of electricity appliances that consumes electricity and vis-vis rises intensity. Total electricity consumption trended upward from in the early 1980 to 1990, falls slightly into 1995 and was relatively constant until around 2010 when it falls sharply. This indicate that, electricity price (tariff) was relatively low and rises the consumption level, whereas from 1990 to 1995 there was a slight increase in the prices until around 2010. However, from 2010 upward, electricity price sharply rises and leads to drastic falls in electricity consumption. Sa ad (2009) stress that like the household's income, price of electricity is another factor affecting electricity consumption. High electricity price may cause households to use less energy in the short-term. In the long-term, this will stimulate the purchase of more efficient appliances whose end product is expected to bring about a substantial reduction in electricity use at a given price. However, the trend of electricity intensity has been upward. Perhaps, this is due to the activities of deregulation that took effects within that period. Among the major contributory factor to the upward trend in electricity intensity is the increasing market share of household appliances. This was triggered by the rise in demand for housing, especially in and around Soul where several new satellite cities have been build (Sa'ad, 2009, International Energy Agency, 1996).

However, despite the gradual decline in residential electricity consumption, the consumption seems to be stable from the period of 1980-2009 but rises rapidly in 2010 and onward. And the intensity has been risen over the years. According to Saad (2009), climate is one of the factors that determine household energy consumption patterns. Anyaka and Edokobi (2014) also note that space heating absorbed almost $70 \%$ of total household energy demand in 1986. In that year cooking only absorbed $14 \%$ of total household energy demand, whilst water heating accounted for an insignificant amount of household energy consumption. These factors, no doubt contributed in no small amount to rising level of residential electricity intensity in Nigeria.

Table 2: Unit Root Test of Stationarity; $H_{0}$ : The Series has a Unit Root

\begin{tabular}{|c|c|c|c|c|c|}
\hline Variables & $\begin{array}{l}\text { ADF } \\
\text { Levels }\end{array}$ & $\begin{array}{l}\text { ADF } \\
\text { Difference }\end{array}$ & $\begin{array}{l}\text { PP } \\
\text { Levels }\end{array}$ & $\begin{array}{l}\text { PP } \\
\text { Difference }\end{array}$ & Remarks \\
\hline LETA & -3.032[]$^{* *}$ & ------ & -3.063[]$^{* *}$ & --------- & $I(0)$ \\
\hline LGDP & -5.649[]$^{* *}$ & ------ & -5.485[]$^{* *}$ & --------- & I (0) \\
\hline LREC & $-1.119[$ ] & -8.736[]$^{* *}$ & -0.842[] & $-13.68[1]^{* *}$ & I (1) \\
\hline \multicolumn{3}{|c|}{$\begin{array}{l}\text { ADF Critical Value at } 5 \%=-2.95 \\
* * \text { indicates sianificant at } 5 \%\end{array}$} & \multicolumn{3}{|c|}{ PP Critical Value at $5 \%=-2.96$} \\
\hline
\end{tabular}

The empty bracket [ ] Indicates that no lag length was included in the test.

\section{Source: e-views 9 Output}

Table 2 shows the result of Augmented Dickey-Fuller (ADF) and Phillip-Perron (PP) unit root test of stationarity for all the variables of the study except Ddrg. The Ddrg was excluded because it is a dummy variable. The test was conducted without lag being included in the optimal lag length options. This method, known as "specific to general" is now embraced by most recent studies as it does not require arbitrary choice of maximum lag length for unit root test. The result in Table 2 shows that for, 
both ADF and PP at levels, ETA and GDP are stationary at levels since their calculated values, in absolute terms, are greater than the critical values at $5 \%$. However, REC is non-stationary at levels but stationary at first difference. Therefore, the variables are integrated of different orders. While ETA and GDP are integrated of order zero [I (0)] REC is integrated of order one [I (1)]. However, none of the variables is integrated of order two [I (2)]. This result satisfies the condition necessary for the use of autoregressive distributed lag (ARDL) model proposed for this study.

Table 3: Bound F- Test for Co-integration

Null Hypothesis: $C(9)=C(10)=C(11)=C(12)=0$

Dependent Variable $\quad$ F- values $\quad$ Remark

\begin{tabular}{cccc}
\hline $\mathrm{D}(\mathrm{LREC})$ & $\mathbf{1 1 . 0 7 *}$ & co-integration exists \\
\hline Pesaran Critical values & Lower bound & Upper bound & \\
& 1.70 & 2.83 & $(10 \%)$ \\
2.47 & 3.18 & $(5 \%)$ \\
2.54 & 3.91 & $(1 \%)$ \\
$*$ denotes existence one co-integrating vector in the endogenous variable $D(D O I)$ is fulfilled \\
$C(9)=R E C, C(10)=G D P, C(11)=E T A, C(12)=$ Ddrg
\end{tabular}

Source: e-views 9 Output

Table 3 shows the result of the bound test for co-integration. The null hypothesis of no co-integration was tested against the alternative hypothesis of presence of co-integration among the variables. The results show that the calculated F-value is 13.16. This value is higher than the Pesanran critical values for all the lower and upper bound limits at $1 \%, 5 \%$ and $10 \%$. This suggests that the null hypothesis of no co-integration cannot be accepted. In other word, the result shows that there is a long-run relationship among the variables of the study.

Table 4: Parsimonious Long-run ARDL Model

\begin{tabular}{lllll}
\hline Variables & Coefficient & Std. Error & t-Statistic & Prob. \\
\hline LREC $(-1)$ & 0.5613 & 0.0799 & 7.0255 & 0.000 \\
LGDP $(-1)$ & 7.5912 & 0.8238 & 0.9215 & 0.367 \\
LETA & -0.4078 & 2.2603 & -0.1804 & 0.086 \\
Ddrg & -0.4314 & 0.8999 & -4.7943 & 0.001 \\
\hline
\end{tabular}

Source: e-views 9 Output

Table 4 shows the result of parsimonious long-run ARDL. The model was tested at lag six, lag four, lag two and the results were compared using Akaike Information Criterion (AIC) and Schwarz Information Criterion (SIC). Results show that model with lag two has the smallest AIC and SIC, suggesting that it is more robust than the other models. Hence model with lag two was selected for this study. From the selected model, estimates that were most insignificant were excluded one at a time and the 
model was re-run after each of the exclusions, until a fairly robust parsimonious result reported in Table 4 is obtained.

From Table 4, residential demand for electricity during the previous one year (REC (-1)) has positive and significant inelastic impact on current residential demand for electricity. $A$ unit increase in REC (-1) increases the elasticity of REC by about 0.56 unit. The inelastic nature of the relationship suggests that the quantity consumed of current electricity changes by a lesser amount for every given unit changes in the quantity of it consumed in the previous year. Also, the relationship between REC and income (GDP (-1)) is positive and elastic but insignificant. A unit increase in GDP (-1) increases the elasticity of REC by about 7.59 units. This implies that a unit increase in income increases residential demand for electricity more than proportionately. This finding agrees with Zaman et.al (2015) that the aggregate demand for electricity is slightly income elastic, the electricity intensity has increased over time and residential demand is fairly income elastic. The finding also corroborates Liu, Gao, Hao, and Liao (2016) that the income elasticity of demand for electricity consumption was approximately one, and remained stable throughout the estimation period.

However, the electricity of price proxies as electricity tariff (ETA) is negatively inelastic with estimated elasticity of about -0.408 . But the estimate is statistically significant at 10 per cent level of probability. This means that residential demand for electricity (REC) decreases with an increase in the price of electricity (ETA) but the decrease in REC is less than proportionate increase in ETA. This is in tandem with the law of demand that price is inversely related with demand, all other things being equal. The finding agrees with Mudassir et. al. (2016) that price of electricity is a major determinant of its demand and is inversely related with it.

Like ETA, deregulation (Ddrg) is negatively related with REC. Its estimated coefficient is about -0.431 . The negative coefficient suggests that the deregulation of the Nigeria power has positive impacts on the consumption of electricity by encouraging efficiency on residential electricity consumption, this led to significant decline in the use of electricity. This suggest that, in response to deregulation in short-run, the trend analysis of intensity, households are becoming more efficient. 
INTERNATIONAL JOURNAL OF ACADEMIC RESEARCH IN BUSINESS AND SOCIAL SCIENCES

Vol. 9, No. 6, June, 2019, E-ISSN: 2222-6990 @ 2019 HRMARS

Table 5 Estimated Short-run Vector Error Correction Model

Dependent Variable (REC)

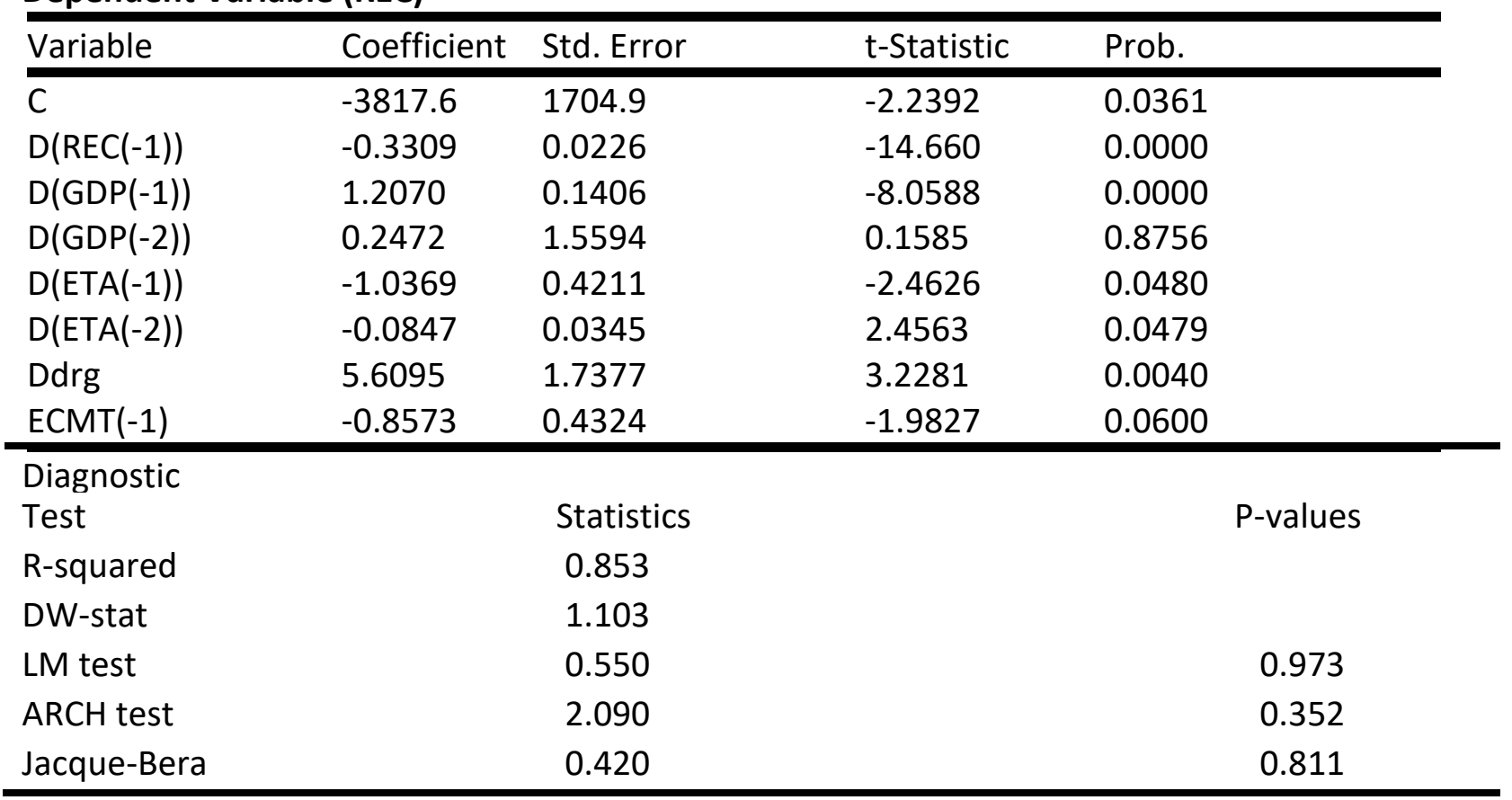

Source: e-views 9 Output

The result of short-run vector error correction model diagnostic test on its estimated result is reported in table 5. From the table 5, the estimated error correction term is negative and significant at $10 \%$ level. The negative sign is as expected. This implies that there is adjustment from short-run to long-run equilibrium among REC, ETA, Ddrg and GDP. In other word, the economy responds to deviations from equilibrium in a balancing manner and as such, if the short run variables (REC, ETA, Ddrg and GDP) deviate from equilibrium, they tend to re-adjust themselves back to equilibrium in the long run.

The coefficient of ECMt indicates an annual speed of adjustment of about $85 \%$ per annum. This suggests that about $85 \%$ of the disequilibrium errors, which occurred the previous year, are corrected in the current year. Furthermore, as shown in Table 5. the one year lags of REC negatively but significantly influences the current REC. Its coefficient of elasticity is 0.33 , suggesting that REC $(-1)$ is inelastic.

Furthermore, the result of diagnostic test shows; income (GDP (-1) and GDP (-2)) has positive elasticity with respect to REC. While GDP $(-1)$ is significant and elastic with estimated coefficient of about 1.2, GDP (-2) is inelastic, insignificant and has an estimated elasticity of about 0.25 . The positive signs of GDP (-1) and GDP (-2) satisfy the a priori expectation. Unlike income, price is negatively elastic with respect to REC. The coefficient of elasticity is greater than one during the previous one year but less than one in the previous two years. For Ddrg, the estimated coefficient is positive. The positive estimate disagrees with the long-run result that deregulation hampers economic growth in Nigeria.

The diagnostic statistics fit the model fairly well. The R-square of the model show that about 85 percent of the variation in dependent variable (REC) is explained by the combined effects of all 
the explanatory variables used in the study, suggesting that about $15 \%$ variation in REC is accounted for by other factors not included in the model. From the table 5. since the Durbin-Watson value of 1.10 is within acceptable limit. It is far from zero suggesting that autocorrelation is low and negligible. This further supported by the result of LM test whose probability value suggests that we cannot reject the null hypothesis of absence of autocorrelation in the model. Furthermore, the probability value for ARCH test is 0.352 . This mean that the null hypothesis of heteroscedasticity cannot be rejected, implying that the series data are homoscedastic.

Figure 2: CUSUM plot of Stability and Plot of Normality

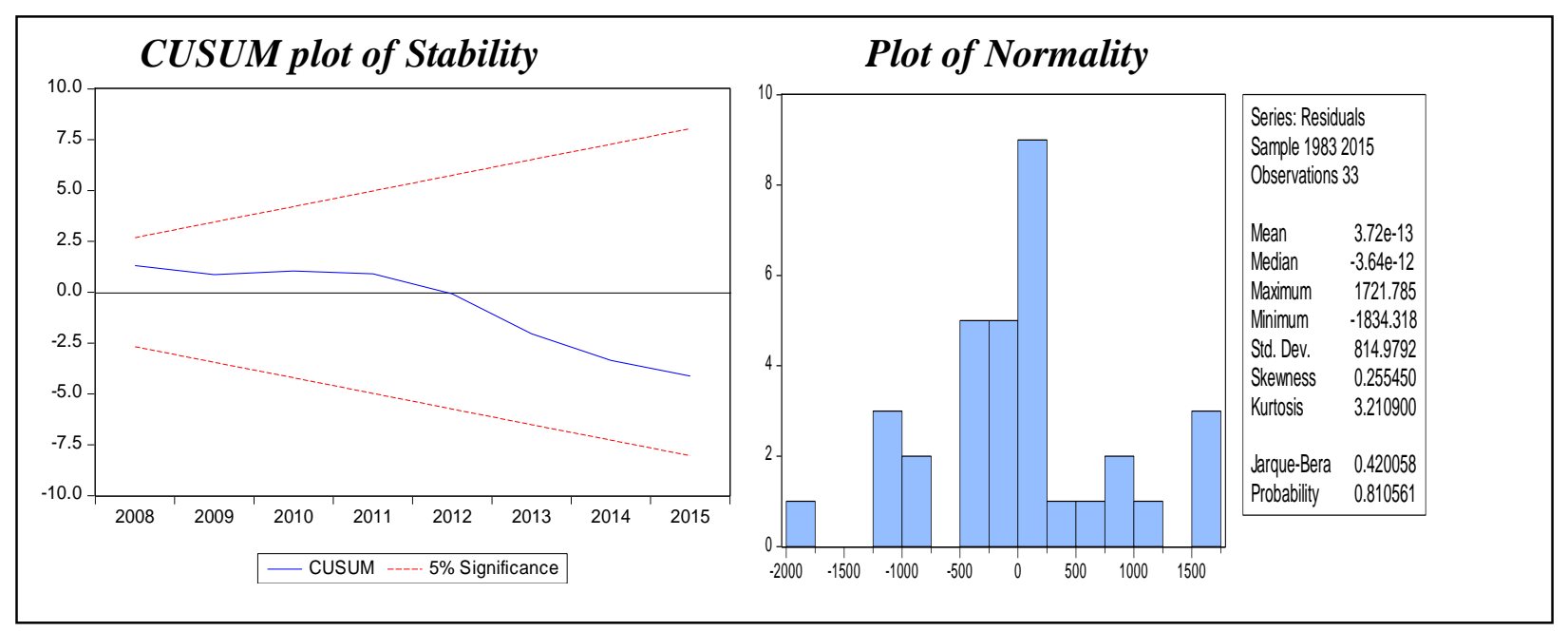

\section{Source: e-views 9 Output}

Figure 2 shows the CUSUM plot of Stability and Jarque-Bera Plot of Normality. The cumulative sum of recursive residuals (CUSUM) plot of stability undertaken to confirm whether the parameters of the model are stable across various sample data shows that the CUSUM plots do not crossed either of the $5 \%$ critical lines. Therefore, it could be concluded that the estimated parameters for the study are stable for the period under study and are useful for policy decision. Similarly, the normality plot shows that the Jarque-Bera estimate and its probability are 0.420 and 0.810 respectively. Hence, the null hypothesis that the error terms of the data set used in the study are stable cannot be rejected.

\section{Conclusion}

This study uses the autoregressive distributed lag model to examine the impact of deregulation on demand for residential electricity in Nigeria over the period 1980 to 2017 . The empirical results reveal that electricity tariff (price), deregulation and income affects residential demand for electricity significantly both in the short-run and in the long-run. The data was estimated using autoregressive distributed lack model (ARDL) approach to cointergrate. The result of the analysis shows the long run relation among the variables. Furthermore, the estimated long run elasticities values are; 0.25 on income GDP and electricity price was -0.408 respectively. Both of them are statistically significant with correct signs. In the other hand, the result of the estimated short run model shows that the error 
correction sign shows the negative value -0.431 on the coefficient of deregulation (dummy) has a negative sign and statistically significant suggesting that deregulation leads to a slight decline in electricity consumption. The overall result does not have any problem of non-normality, autocorrelation, heterestidascity or non-stability. The policy implications of the result suggest that in addition to the pricing policies government should also use enlightenment campaign to educate people to be efficient in using electricity

\section{Recommendations}

The results of the study imply that considerable changes must occur before we can observe a higher level of stability or increases in the level of residential electricity consumption in Nigeria. Therefore, to ensure the sustainable development of the electric power industry, introducing higher energy efficiency standards for electrical appliances, organizing appropriate pricing policies and improving income levels are vital. In addition, the government should emphasize electricity conservation in the industrial sector rather than in the residential sector.

From the above implications suggested by the result, however, deregulation impacts cannot be attaining without adherence to observations above and more others. Proper investment policies in both technical and non-technical aspects through technical expertise in order to ensure that better service is rendered to consumers at affordable rates on the basis of pricing schemes to promote load management. Demand-driven pricing provides customers with an incentive to minimize their energy consumption. Policy should be made to ban the importation, But the manufacturing and use of local equipment and appliance in Nigeria. Such policy should encourage the gradual phase out of local equipment in the system and encourage the phase in of energy modern once. Considering the relevance of energy efficiency for national development, it will be necessary for government to set up additional ministry or agency that will be responsible for promoting energy efficiency.

\section{References}

Adebola, S. S. (2011), Electricity Consumption and Economic Growth: Trivariate investigation in Botswana with real capital formation. International Journal of Energy Economics and Policy. www.ecojournals.com.

Aminu, I. Peterside., \& Brown Z. (2014). The Impact of Privatization of Power Sector in Nigeria: A Political Economy Approach Mediterranean Journal of Social Sciences Vol 5 No 26.

Anyaka \& Edokobi. (2014). The Negative Impact of High Electricity Tariff on Consumers/EndUsers in Some Developing Countries, Journal of Electrical and Electronics Engineering, Volume 9, PP 27- 34.

Baumol, W. J. (1982). Contestable Markets: An Uprising in the Theory of Industry Structures, American Economic Review, 72(1), 1-15.

Babatunde, M. A., \& Shuaibu, M. I. (2014). The demand for residential electricity in Nigeria. A paper presented at the 2009 conference of the African Econometric Society (AES).

CBN. (2009). Statisitical Bulletin (December), Vol. 21. Abuja: A publication of Central Bank of Nigeria, (Chapter 12) 
INTERNATIONAL JOURNAL OF ACADEMIC RESEARCH IN BUSINESS AND SOCIAL SCIENCES

Vol. 9, No. 6, June, 2019, E-ISSN: 2222-6990 @ 2019 HRMARS

Di Bella., G., \& Grigoli, F. (2016). Strengthening the Electricity Sector to Improve Efficiency and Support Economic Activity1 IMF Working Paper

Ezeani, E. O (2004). Industrial Democracy in Theoretical and Empirical Analysis, Nigerian Journal of Public Administration and Local Government.Vol.6 No.1.

Eguabor., \& R. E. (2014). Mmetered and Unmetered Billing: How Asymmetric Are the Phcn Bills? Journal of Social Economics Research, 2014, 1(5): 97-107

Gupta, E. (2011). Climate Change and the Demand for Electricity: A Non-Linear Time Varying Approach, Indian Statistical Institute, Delhi, Working Paper, December 6.

Girish, G. P., \& Vijayadashami, S. (2013). Determinants of Electricity Price in Competitive Power Market. International Journal of Business and management; Vol. 8, No. 21;1

Holtedahl, P., and Joutz, F. L. (2004). Residential electricity demand in Taiwan. Energy Economics, 26, 201-224. I

Isola., \& Wakeel, A. (2012). An Analysis of Electricity Market structure and its Implications for Energy Sector Reforms and Management in Nigeria Global Advanced Research Journal of Management and Business Studies Vol. 1(5) pp. 141-149,

Liu, Y., Gao, Y., Hao, Y., \& Liao, H. (2016). The Relationship between Residential Electricity Consumption and Income. An Article in African Society for Scientific Research (ASSR).

Nwachukwu, M. U., Ezedinma, N. F., \& Jiburum, U. (2014). Comparative Analysis of Electricity Consumption among Residential, Commercial and Industrial Sectors of the Nigeria's Economy Journal of Energy Technologies and Policy www.iiste.org (Online) Vol.4

Ojobo, J. A. (2005) The impact of Privatization Policy on Labor in Africa: A Political Economy Approach. The Nigerian Journal of Administrative Studies, Vol 3, No 1.1

Paul, A., E. Myers, \& K. Palmer. (2009). "A Partial Adjustment Model of U.S. Electricity Demand by Region, Season, and Sector". Resource for the Future Discussion Paper 0850, Washington, DC, April.

Payne, J. E. (2010), A survey of the electricity consumption-growth literature. Journal of Applied Energy, 87(3), 723-731.

Sa'ad, S. (2009). Electricity demand for South Korean residential sector, journal Homepage: www.elsevier.com/locate/enpol Energy Policy.

Tewathia, N. (2014). Determinants of the Household Electricity Consumption International Journal of Energy Economics and Policy Vol. 4, No. 3, 2014, pp.337-348

Wolde, R. Y. (2005). Energy Demand and Economic Growth: African Experience. Journal of Policy Modeling. Vol. 27, Cambridge Working Paper.

Sun, Y. (2015). Electricity Prices, Income and Residential Electricity consumption. East China Normal, Working Paper.

Zaman, M., Shaheen F., Haider A., \& Qamar. (2015). Examining Relationship between Electricity Consumption and its Major Determinants in Pakistan. International Journal of Energy Economics and Policy, 5(4), 998-1009. Available at http: www.econjournals.com 